\title{
ANALISIS PENGARUH KARAKTERISTIK WILAYAH (KELURAHAN) TERHADAP BANYAKNYA KASUS DEMAM BERDARAH DENGUE (DBD) DI KOTA SEMARANG
}

\author{
Rita Rahmawati ${ }^{1}$, Kartono $^{2}$, Robertus Heri Sulistyo ${ }^{2}$, Betha Noranita ${ }^{3}$, \\ Eko Adi Sarwoko ${ }^{3}$, Asep Yoyo Wardaya ${ }^{4}$ \\ ${ }^{1}$ Staf Pengajar Jurusan Statistika FSM Universitas Diponegoro \\ ${ }^{2}$ Staf Pengajar Jurusan Matematika FSM Universitas Diponegoro \\ ${ }^{3}$ Staf Pengajar Jurusan Informatika FSM Universitas Diponegoro \\ ${ }^{4}$ Staf Pengajar Jurusan Fisika FSM Universitas Diponegoro
}

\begin{abstract}
DBD still become one of the major problems of public health in Indonesia because the death rate tended sufferers to increase from year to year. Incredible happening (KLB) of DBD which was initially occurring every five years, now it's getting often happens. In the city of Semarang, during 2009 occurring 165 times KLB in urban village, 35 times KLB in the level of community health centers and 15 times KLB at the district level. Though the number of DBD cases in 2009 from 2008 was declining, but in this year also noted that the number of deaths resulting from DBD increased to 43 people from 18 people in 2008. This research aims to analyze the characteristics of the neighborhood (whose data is always updated by BPS via PODES) that affect the number of cases of DBD (whose data is always updated by DKK) in Semarang city, by creating the best regression models using stepwise technique. Regression model analysis of results obtained best is $\mathrm{Y}=23.029+0.004 \mathrm{X} 1-0.074 \mathrm{X} 2+0.070 \mathrm{X} 3$, where $\mathrm{Y}$ is IR/10000 PDDK, that is the number of residents affected by DBD for each 10000 inhabitants, $\mathrm{X} 1$ is the number of residents aged 15-24 years, $\mathrm{X} 2$ is total area of land of rice fields and $\mathrm{X} 3$ is area of land for buildings and grounds around the page.
\end{abstract}

Keywords: DBD, Characteristics of the Neighborhood, Regression, Stepwise

\section{Pendahuluan}

Demam Berdarah Dengue (DBD) merupakan salah satu penyakit yang sering menimbulkan wabah dan menyebabkan kematian. Penyakit yang ditularkan oleh nyamuk Aides aegypti ini masih menjadi salah satu masalah utama kesehatan masyarakat di Indonesia karena angka kematian penderitanya cenderung meningkat dari tahun ke tahun. Kejadian Luar Biasa (KLB) penyakit DBD yang semula terjadi setiap 5 tahun, kini semakin sering terjadi. Tahun 2004, kasus DBD menjadi KLB di 12 provinsi dengan jumlah penderita 79462 orang dan 957 diantaranya meninggal. Awal tahun 2007, kembali terjadi KLB di 11 provinsi di Indonesia. Jumlah kasus DBD 2007 hingga Juli 2007 tercatat sebanyak 102175 kasus dengan jumlah kematian mencapai 1098 jiwa $^{[2]}$.

DBD di Indonesia mulai dikenal pada tahun 1968 di Surabaya dengan jumlah penderita 58 orang dan kematian 24 orang (41.3\%). Penyakit ini menyebar ke seluruh wilayah Indonesia, sehingga pada tahun 1980 seluruh provinsi di Indonesia telah terjangkit penyakit ini. Banyak upaya untuk memberantas perkembangan penyakit ini telah dilakukan, yang mengarah pada pembatasan gerak dan populasi nyamuk sebagai vektor DBD pada manusia, diantaranya program yang paling sering dikampanyekan yaitu program 3M (menguras, menutup dan mengubur). Kegiatan pokok pemerintah dalam pemberantasan DBD tidak hanya meliputi penemuan kasus, pengobatan bagi penderitanya 
serta penyemprotan di lokasi kasus $\mathrm{DBD}$, namun juga dilakukan pengamatan terhadap wilayah penderita. Pada tahun 1980 sampai dengan 1985, program kegiatan pemberantasan DBD dikembangkan dengan melaksanakan abatisasi massal bagi kota-kota dengan endemisitas DBD tinggi yang meliputi seluruh wilayah Indonesia. Abatisasi massal ini kemudian dipertajam sasarannya melalui stratifikasi wilayah endemis dan non endemis, yang dalam perkembangannya status wilayah terbagi menjadi 4 strata yaitu endemis, sporadis, potensial dan bebas ${ }^{[4]}$.

Di Kota Semarang, Profil Kesehatan Kota Semarang Tahun 2009 mencatat ada sebanyak 3883 kasus DBD pada tahun tersebut. Jumlah ini mengalami penurunan yang cukup signifikan dari tahun 2008 yang mencapai 5249 kasus atau turun 26\%. Kasus bulanan DBD tertinggi dari tahun 2004 hingga 2009 adalah pada bulan Februari 2004, bulan Januari, Februari, April, Mei, Oktober dan Nopember 2008, serta bulan Juni, Juli dan Agustus 2009. Kota Semarang mengalami KLB pada bulan Januari 2009 (kenaikan 2 kali atau lebih dari bulan Desember 2008), Juni, Juli, Agustus, September dan Desember 2009 karena terjadi kenaikan 2 kali lipat atau lebih dari bulan yang sama tahun sebelumnya. Sampai dengan berakhirnya tahun 2009 masih terjadi KLB di 50 kelurahan, 14 puskesmas dan 7 kecamatan di Kota Semarang. Selama tahun 2009 terjadi 165 kali KLB di tingkat kelurahan, 35 kali KLB di tingkat puskesmas dan 15 kali KLB di tingkat kecamatan. Meskipun jumlah kasus DBD pada tahun 2009 menurun dari tahun 2008, namun dalam Profil Kesehatan Kota Semarang Tahun 2009 juga tercatat bahwa jumlah kematian akibat DBD mengalami kenaikan menjadi 43 orang dari 18 orang pada tahun 2008.

Masih maraknya masalah DBD ini membuat banyak kalangan yang meneliti dan menganalisis faktor risiko kejadian DBD. Penelitian yang telah banyak dilakukan, adalah dengan melihat faktor perilaku masyarakat serta penelitian DBD yang lebih menyoroti dari sisi kesehatan, walaupun kasus DBD juga sangat mungkin dipengaruhi oleh keadaan (karakter) lokasi atau ruang (space) yaitu wilayah atau kelurahan tempat masyarakat bermukim. Hasil pendataan Dinas Kesehatan mencatat bahwa pada tahun 2009, kelurahan tanpa penderita DBD didominasi oleh kelurahan di wilayah Gunungpati dan Mijen yang berada di daerah perbukitan. Ini berarti memungkinkan kondisi wilayah mempengaruhi endemisitas DBD di Kota Semarang. Untuk itu, dalam penelitian ini akan dianalisis karakteristik wilayah yang secara statistika mempengaruhi endemisitas DBD dalam rangka mengembangkan sistem informasi deteksi dini kejadian luar biasa DBD. Unit pengamatannya adalah wilayah dengan tingkat kelurahan, yaitu sebanyak 177 kelurahan di Kota Semarang. Sedangkan data karakteristik kelurahan diperoleh dari data PODES (Potensi Desa) yang dilakukan oleh BPS secara rutin.

\section{Tinjauan Pustaka}

\subsection{Analisis Regresi}

Analisis regresi berkenaan dengan studi ketergantungan satu variabel tak bebas, pada satu atau lebih variabel lain yang menjelaskan (variabel bebas), dengan maksud menaksir dan/atau meramalkan nilai rata-rata (populasi) variabel tak bebas, berdasarkan nilai yang diketahui atau tetap (dalam pengambilan sampel berulang) dari variabel yang menjelaskan ${ }^{[3]}$.

Model regresi linear dengan k variabel bebas, dituliskan sebagai berikut:

$$
Y_{i}=\beta_{1}+\beta_{2} X_{2 i}+\beta_{3} X_{3 i}+\ldots+\beta_{k} X_{k i}+u_{i}, i=1,2, \ldots, n
$$

dengan: $\beta_{1}=$ intersep

$$
\beta_{2} \text { sampai } \beta_{\mathrm{k}}=\text { koefisien kemiringan parsial }
$$




$$
\begin{aligned}
& \mathrm{u}=\text { unsur gangguan stokhastik } \\
& \mathrm{Y}_{\mathrm{i}}=\text { nilai Y pada observasi ke-i } \\
& \mathrm{n}=\text { ukuran sampel }
\end{aligned}
$$

Dalam bentuk matriks, Persamaan (1) dapat dituliskan sebagai ${ }^{[3]}$ :

$$
\mathbf{Y}=\mathbf{X} \boldsymbol{\beta}+\mathbf{U}
$$

dengan:

$$
\mathbf{Y}=\left[\begin{array}{c}
Y_{1} \\
Y_{2} \\
\ldots \\
Y_{N}
\end{array}\right], \quad \mathbf{X}=\left[\begin{array}{ccccc}
1 & X_{11} & X_{21} & \ldots & X_{k 1} \\
1 & X_{12} & X_{22} & \ldots & X_{k 2} \\
\ldots & \ldots & \ldots & \ldots & \ldots \\
1 & X_{1 n} & X_{2 n} & \ldots & X_{k N}
\end{array}\right], \quad \boldsymbol{\beta}=\left[\begin{array}{c}
\beta_{1} \\
\beta_{2} \\
\ldots \\
\beta_{k}
\end{array}\right], \quad \mathbf{U}=\left[\begin{array}{c}
u_{1} \\
u_{2} \\
\ldots \\
u_{n}
\end{array}\right]
$$

Asumsi yang mendasari model regresi linear klasik, dalam notasi matriks:

1. $\mathrm{E}(\mathbf{U})=\mathbf{0}$ dimana $\mathbf{U}$ dan $\mathbf{0}$ adalah vektor kolom $\mathrm{Nx} 1$ dan $\mathbf{0}$ merupakan vektor nol

2. $\mathbf{E}\left(\mathbf{U} \mathbf{U}^{\mathrm{T}}\right)=\sigma^{2} \mathbf{I}$, dimana $\mathbf{I}$ adalah matriks identitas dengan ukuran $\mathrm{NxN}$

3. Matriks $\mathbf{X}$ tidak stokhastik

4. Rank (derajat) dari $\mathbf{X}$ adalah k (banyaknya kolom dalam $\mathbf{X}$ ) dan k lebih kecil dari $\mathrm{N}$ (banyaknya observasi)

\subsection{Metode Stepwise dalam Regresi}

Model Regresi seringkali diperoleh dari beberapa tahap sebelum dihasilkan model terbaik. Salah satunya adalah dengan menentukan variabel mana yang seharusnya dimasukkan ke dalam model dari sejumlah variabel bebas yang tersedia. Variabel bebas terbaik (yaitu yang berkorelasi paling kuat dengan variabel tak bebas) akan digunakan pertama kali, kemudian yang terbaik kedua dan seterusnya. Prosedur seperti ini dikenal dengan Regresi Stepwise.

Regresi stepwise melibatkan dua jenis proses yaitu forward selection dan backward elimination. Teknik ini dilakukan melalui beberapa tahapan. Pada masing-masing tahapan akan diputuskan variabel bebas mana yang dimasukkan ke dalam model dan variabel mana yang dihilangkan karena berkorelasi dengan variabel bebas lain dalam model. Proses ini dilakukan terus menerus hingga tidak ada lagi variabel yang memenuhi kriteria untuk ditambahkan atau dihilangkan sehingga akan diperoleh model regresi terbaik.

\section{Data dan Metode}

\subsection{Data}

Dalam penelitian ini, digunakan data seluruh kelurahan di wilayah Kota Semarang, yaitu sebanyak 177 kelurahan dari 16 Kecamatan yang ada di wilayah Kota Semarang. Ke-enambelas kecamatan tersebut yaitu; Kecamatan Banyumanik, Candisari, Gajahmungkur, Gayamsari, Genuk, Gunungpati, Mijen, Ngaliyan, Pedurungan, Semarang Barat, Semarang Selatan, Semarang Tengah, Semarang Timur, Semarang Utara, Tembalang dan Kecamatan Tugu. Data yang digunakan merupakan data sekunder yang diperoleh dari:

1. BPS Kota Semarang.

Data diambil dari Kecamatan Dalam Angka (KDA) tahun 2010, yaitu tahun terbaru (saat penelitian ini dimulai) KDA yang telah dipublikasikan oleh BPS. Dalam KDA, unit pengamatan adalah Kelurahan, dengan beberapa hal yang diukur yaitu 
tentang Geografi, Pemerintahan, Kependudukan, Sosial, Pertanian, Perekonomian, serta Transportasi dan Komunikasi ${ }^{[1]}$.

Pada penelitian ini digunakan data:

a. Geografi, yaitu variabel yang mengukur Penggunaan Areal Tanah, dengan rincian luasan tanah sawah dan tanah kering. Tanah sawah sendiri terdiri dari tanah sawah teknis, setengah teknis, sederhana, tadah hujan serta sawah lainnya, termasuk tanah sawah (basah) yang sementara tidak diusahakan. Sedangkan tanah kering terdiri dari pekarangan untuk bangunan dan halaman, tegal atau kebun, gembalaan (padang rumput) atau lapangan, kolam, tambak serta perkebunan dan lainnya.

b. Kependudukan. Pada bagian Kependudukan dalam KDA, digunakan data jumlah penduduk menurut kelompok usia, mulai dari kelompok 0-4 tahun, 5-9 tahun, 10-14 tahun, dan seterusnya hingga kelompok usia 75 tahun atau lebih.

c. Sosial. Pada bagian Sosial ini digunakan data mengenai banyaknya sekolah dan murid untuk tingkat TK, SD, SLTP dan SLTA.

2. Dinas Kesehatan Kota (DKK) Semarang.

Data yang diambil dari DKK adalah terkait jumlah kasus DBD pada tahun 2010 di seluruh Kelurahan yang ada di Kota Semarang. Besaran kasus DBD oleh DKK diukur dalam IR/10000 PDDK, yang menunjukkan banyaknya warga yang terkena DBD untuk setiap 10000 penduduk yang ada pada setiap kelurahan.

Pertimbangan dalam pemilihan data pada penelitian ini adalah, bahwa data mengenai karakteristik kelurahan selalu tersedia setiap tahun yang dikumpulkan oleh BPS melalui kegiatan PODES. Demikian juga dengan data jumlah kasus DBD yang selalu dipantau dan dicatat oleh DKK. Pemanfaatan data dengan lebih optimal diharapkan dapat memberi kontribusi mengenai faktor-faktor yang mengkin mempengaruhi banyaknya kasus DBD yang terjadi.

\subsection{Metode Analisis}

Langkah-langkah analisis yang dilakukan dalam penelitian ini dapat dirumuskan sebagai berikut:

1. Analisis awal dimulai dengan seleksi variabel yang diperoleh dari BPS Kota Semarang, sebagai variabel bebas (independent variabel). Seleksi atau pemilihan variabel ini dilakukan dengan beberapa pertimbangan yaitu:

a. Kemungkinan adanya keterkaitan dengan kasus DBD.

b. Kelengkapan data yang terdapat dalam semua Kelurahan dalam Kecamatan yang ada dalam KDA. Hal ini mengingat bahwa tidak semua variabel yang seharusnya diukur terdapat dalam setiap Kecamatan dalam KDA 2010 yang dipublikasikan. Pertimbangan kelengkapan data dilakukan untuk menghindari missing data (data hilang) yang dapat mengurangi validitas dari hasil analisis.

2. Uji Korelasi variabel.

Uji korelasi dilakukan terhadap semua variabel yang terdapat pada setiap KDA secara keseluruhan.

3. Analisis Regresi.

Dalam penelitian ini digunakan analisis regresi linear berganda, dengan variabel tak bebas (Y) adalah IR/10000 PDDK. Metode regresi yang digunakan adalah stepwise sehingga pemilihan variabel bebas yang digunakan melibatkan semua variabel yang memenuhi langkah 1 metode analisis ini.

4. Pemodelan.

Hasil pemodelan berupa persamaan regresi yang menghasilkan pendugaan terbaik. 
5. Untuk keperluan analisis dan pengolahan data digunakan perangkat lunak (software) SPSS 11.5 dan Minitab 14.

\section{Hasil dan Pembahasan}

Variabel-variabel bebas yang digunakan dalam pengujian mengenai pengaruhnya terhadap banyaknya kasus DBD berdasarkan analisis awal ada sebanyak 23 variabel, yang terdiri dari:

a. Sebanyak 8 variabel tentang luas dari jenis-jenis pemanfaatan tanah dan geografis, yaitu:

i. Luas lahan sawah teknis

ii. Luas lahan sawah setengah tehnis

iii. Luas lahan sawah tadah hujan

iv. Luas lahan pekarangan untuk bangunan dan halaman sekitar

v. Luas keseluruhan tanah sawah

vi. Luas keseluruhan tanah kering

vii. Luas wilayah kelurahan

viii. Kepadatan penduduk per hektar

Semua luasan wilayah dalam satuan hektar (ha).

b. Sebanyak 4 variabel mengenai golongan usia, yaitu umur 0-14 tahun, 15-24 tahun, 25-39 tahun dan 40 tahun atau lebih.

c. Sebanyak 11 variabel mengenai banyaknya bangunan sekolah, murid maupun guru dari tingkatan SD, SLTP hingga SLTA atau gabungannya.

Analisis selanjutnya digunakan 23 variabel di atas untuk melihat kedekatannya dengan banyaknya kasus DBD pada tiap wilayah Kelurahan. Uji korelasi dilakukan untuk tujuan ini, dan hasilnya menunjukkan variabel-variabel berikut ini memiliki korelasi (hubungan) yang signifikan dengan banyaknya kasus DBD:

1. Luas lahan sawah setengah teknis

2. Luas lahan sawah tadah hujan

3. Luas lahan pekarangan untuk bangunan dan halaman sekitar

4. Luas keseluruhan tanah sawah

5. Banyaknya penduduk usia 0-14 tahun

6. Banyaknya penduduk usia 15-24 tahun

7. Banyaknya penduduk usia 25-39 tahun

8. Banyaknya penduduk usia 40 tahun atau lebih

9. Banyaknya sekolah SD

10. Banyaknya murid SD

11. Banyaknya guru SD

12. Banyaknya sekolah SLTP, dan

13. Banyaknya sekolah SLTP dan SLTA

Meskipun ketiga belas variabel di atas secara signifikan berkorelasi dengan banyaknya kasus DBD, namun ditemukan juga bahwa di antara variabel-variabel tersebut terjadi multikolinieritas yang secara statistika akan mengganggu hasil pemodelan akhir. Untuk mengatasi hal tersebut, analisis yang digunakan untuk memilih variabel-variabel bebas yang dapat digunakan agar mendapatkan persamaan terbaik adalah analisis regresi stepwise. ANOVA dan masing-masing koefisien dari analisis ini dapat dilihat pada Tabel 1 dan Tabel 2. 
Tabel 1. ANOVA Regresi Stepwise

\begin{tabular}{|c|c|c|c|c|c|}
\hline Model & $\begin{array}{c}\text { Jumlah } \\
\text { Kuadrat }\end{array}$ & Db & $\begin{array}{l}\text { Kuadrat } \\
\text { Tengah }\end{array}$ & F-hit & Sig. \\
\hline 1 Regresi & 10462.848 & 1 & 10462.848 & 26.792 & $0.000^{\mathrm{a}}$ \\
\hline Residual & 68340.516 & 175 & 390.517 & & \\
\hline Total & 78803.364 & 176 & & & \\
\hline 2 Regresi & 12550.581 & 2 & 6275.291 & 16.481 & $0.000^{\mathrm{b}}$ \\
\hline Residual & 66252.783 & 174 & 380.763 & & \\
\hline Total & 78803.364 & 176 & & & \\
\hline \multirow{3}{*}{$\begin{array}{ll}3 \text { Regresi } \\
\text { Residual } \\
\text { Total }\end{array}$} & 14797.509 & 3 & 4932.503 & 13.332 & $0.000^{\mathrm{c}}$ \\
\hline & 64005.855 & 173 & 369.976 & & \\
\hline & 78803.364 & 176 & & & \\
\hline
\end{tabular}

Keterangan:

a. Prediktor: (konstanta), Banyaknya penduduk usia 15-24 tahun

b. Prediktor: (konstanta), Banyaknya penduduk usia 15-24 tahun, Luas keseluruhan tanah sawah

c. Prediktor: (konstanta), Banyaknya penduduk usia 15-24 tahun, Luas keseluruhan tanah sawah, Luas lahan pekarangan untuk bangunan dan halaman sekitar

d. Peubah tak bebas: IR/10000 PDDK

Dari Tabel 1, dapat disimpulkan bahwa berdasarkan data yang digunakan, persamaan terbaik adalah yang melibatkan 3 variabel bebas yaitu Banyaknya penduduk usia 15-24 tahun (X1), Luas keseluruhan tanah sawah (X2) dan Luas lahan pekarangan untuk bangunan dan halaman sekitar (X3). Sedangkan dari Tabel 2, dapat diperoleh model yang dihasilkan adalah, bahwa banyaknya kasus DBD dapat diduga dengan persamaan:

$$
\mathrm{Y}=23.029+0.004 \times 1-0.074 \times 2+0.070 \times 3
$$

dengan

$$
\begin{aligned}
\mathrm{Y} & =\mathrm{IR} / 10000 \text { PDDK, yaitu banyaknya warga yang terkena DBD untuk setiap } \\
& 10000 \text { penduduk } \\
\mathrm{X} 1 & =\text { Banyaknya penduduk usia } 15-24 \text { tahun } \\
\mathrm{X} 2 & =\text { Luas keseluruhan tanah sawah } \\
\mathrm{X} 3 & =\text { Luas lahan pekarangan untuk bangunan dan halaman sekitar }
\end{aligned}
$$

Tabel 2. Koefisien Regresi Stepwise

\begin{tabular}{crrrrr}
\hline \multirow{2}{*}{ Model } & Koefisien tidak standar & $\begin{array}{c}\text { Koefisien } \\
\text { standar }\end{array}$ & t-hit & Sig. \\
\cline { 2 - 4 } & $\mathbf{B}$ & $\begin{array}{c}\text { Standar } \\
\text { error }\end{array}$ & Beta & & \\
\hline 1 konstanta) & 22.212 & 2.531 & & 8.775 & 0.000 \\
X1 & 0.006 & 0.001 & 0.364 & 5.176 & 0.000 \\
\hline 2 konstanta) & 25.047 & 2.777 & & 9.091 & 0.000 \\
X1 & 0.006 & 0.001 & 0.321 & 4.461 & 0.000 \\
X2 & -0.061 & 0.026 & -0.168 & -2.342 & 0.020 \\
\hline konstanta) & 23.029 & 2.858 & & 8.059 & 0.000 \\
X1 & 0.004 & 0.001 & 0.206 & 2.427 & 0.016 \\
X2 & -0.074 & 0.026 & -0.205 & -2.833 & 0.005 \\
X3 & 0.070 & 0.029 & 0.202 & 2.464 & 0.015 \\
\hline
\end{tabular}




\section{Kesimpulan}

Beberapa kesimpulan yang dapat diambil dari penelitian ini adalah:

1. Berdasarkan ketersediaan data karakteristik wilayah kelurahan dan jumlah kasus DBD, terdapat 13 variabel bebas yang berkorelasi kuat dengan jumlah kasus DBD setiap wilayah kelurahan.

2. Dari 13 variabel bebas yang berkorelasi, diperoleh model regresi terbaik berdasar metode stepwise yaitu $\mathrm{Y}=23.029+0.004 \mathrm{X} 1-0.074 \mathrm{X} 2+0.070 \mathrm{X} 3$, dimana $\mathrm{Y}=\mathrm{IR} / 10000$ PDDK, yaitu banyaknya warga yang terkena DBD untuk setiap 10000 penduduk, $\mathrm{X} 1$ = Banyaknya penduduk usia 15-24 tahun, $\mathrm{X} 2=$ Luas keseluruhan tanah sawah, X3 = Luas lahan pekarangan untuk bangunan dan halaman sekitar.

3. Nilai positif pada koefisien X1 dan X3 menunjukkan bahwa semakin banyak penduduk usia 15-24 tahun atau semakin besar luas lahan pekarangan untuk bangunan dan halaman sekitar, maka semakin banyak kasus DBD pada suatu Kelurahan. Sedangkan nilai negatif pada koefisien X2 menunjukkan bahwa semakin besar luas tanah sawah, maka kecenderungannya akan semakin sedikit banyaknya kasus DBD.

\section{DAFTAR PUSTAKA}

1. BPS, Kecamatan dalam Angka tahun 2010, Semarang, 2010.

2. Gama, T.A. and Betty, R.F., Analisis Faktor Risiko Kejadian DBD di Desa Mojosongo Kabupaten Boyolali, Eksplanasi, Volume 5 Nomor 2 Edisi Oktober 2010, Surakarta.

3. Gujarati, D., Ekonometrika Dasar, Erlangga, Jakarta, 1999.

4. Hiswani, Pencegahan dan Pemberantasan Demam Berdarah Dengue (DBD), USU Digital Library, Sumatera Utara, 2003, http://library.usu.ac.id/download/fkm/fkmhiswani9.pdf (diakses pada Desember 2012). 